\title{
IMPLEMENTASI PENDEKATAN CONTEXTUAL TEACHING AND LEARNING (CTL) TERHADAP KEMAMPUAN BERPIKIR KRITIS SISWA
}

\author{
Wakijo $^{1}$, Siti Suprihatin ${ }^{2}$ \\ Pendidikan Ekonomi FKIP Universitas Muhammadiyah Metro \\ Wakijoummetro@yahoo.co.id ${ }^{1}$, sitisuprihatin43@yahoo.co.id ${ }^{2)}$
}

\begin{abstract}
Abstrak
Penelitian ini merupakan penelitian Quasi eksperimen dengan menggunakan pendekatan kuantitatif karena peneliti tidak merubah keadaan kelompok awal sampel. Desain penelitian dalam ini yaitu "the nonequivalent posttest-only control group design". Penelitian ini dilaksanakan di Sekolah Menengah Pertama (SMP) Tulang Bawang Barat Provinsi Lampung. Populasi dalam penelitian ini adalah seluruh siswa kelas VIII di SMP Tulang Bawang Barat. Pendekatan Contextual Teaching and Learning (CTL) merupakan konsep belajar yang membantu guru mengaitkan antara materi yang diajarkan dengan situasi dunia nyata siswa, dan mendorong siswa membuat hubungan antara pengetahuan yang dimilikinya dengan penerapannya dalam kehidupan mereka sehari-hari. Berpikir kritis merupakan kemampuan untuk memahami masalah, menyeleksi informasi yang penting untuk menyelasaikan masalah, memahami asumsi-asumsi, merumuskan dan menyelasaikan hipotesis yang relevan, serta menarik kesimpulan yang valid dan menentukan kevalidan dari kesimpulan-kesimpulan. Berdasarkan peneliitian yang telah dilakukan dan berdasarkan hasil uji perbedaan rataan postes kelas eksperimen dan kelas kontrol tersebut diketahui bahwa nilai Sig. (2-tailed) yaitu 0,038 lebih kecil dari nilai $\alpha=0,05$, sehingga $\mathrm{H}_{0}$ ditolak. Hasil ini berarti kedua kelas memiliki kemampuan berpikir kritis yang berbeda secara signifikan. Kemampuan berpikir kritis siswa yang mendapat pembelajaran pendekatan Contextual Teaching and Learning $(C T L)$ lebih tinggi dari pada siswa yang mendapat pembelajaran konvensional. Sehingga dapat disimpulkan bahwa terdapat pengaruh pendekatan Contextual Teaching and Learning (CTL) terhadap berpikir kritis siswa pada mata pelajaran ekonomi.
\end{abstract}

\section{Kata Kunci: Pendekatan Contextual Teaching And Learning (CTL), Berpikir Kritis}

\section{PENDAHULUAN}

Pendidikan sebagai usaha mencerdaskan kehidupan bangsa dan membentuk manusia seutuhnya, serta ikut menunjang keberhasilan pembangunan nasional. Menurut Undang-Undang No. 20 Tahun 2004 Pendidikan merupakan usaha sadar dan terencana untuk mengembangkan segala potensi yang dimiliki peserta didik melalui proses pembelajaran. Pendidikan adalah suatu usaha membentuk manusia seutuhnya dan dewasa. Dewasa di sini bukanlah dewasa secara fisik tetapi dewasa secara psikologis. Dewasa secara psikologis mempunyai banyak ciri, seperti kemerdekaan berpikir, independensi dan penalaran moral yang baik. Pendidikan pada hakekatnya merupakan suatu upaya mewariskan nilai yang akan menjadi penolong dan penentu umat manusia dalam menjalani kehidupan, dan sekaligus 
untuk memperbaiki nasib dan peradaban umat manusia. Tanpa pendidikan, manusia sekarang tidak berbeda dengan generasi manusia masa lampau, yang sangat tertinggal baik kualitas kehidupan maupun proses-proses pemberdayaannya.

Menurut Anita dalam Cooperative Learning (2006), situasi dalam kelas perlu direncanakan dan dibangun sedemikian rupa sehingga siswa mendapatkan kesempatan untuk berinteraksi satu sama lain. Dalam interaksi ini, akan terbentuk suatu komunitas yang memungkinkan mereka untuk memahami proses belajar dan memahami satu sama lain. Melalui pembelajaran kooperatif, diharapkan guru dapat mengelola kelas dengan lebih efektif. Metode pendekatan Contextual Teaching and Learning (CTL) dalam proses pembelajaranya siswa dituntut ikut aktif dalam proses kegiatan pembelajaran yang berlangsung.

Berdasarkan hasil observasi awal, penulis melihat bahwa kurang bervariasinya metode pembelajaran yang digunakan guru dalam proses belajar. Metode pembelajran yang diterapkan masih berpusat pada guru (teacher centered). Guru adalah sumber informasi, kegiatan siswa dalam proses pembelajaran hanya mendengar dan mencatat informasi yang diberikan sehingga siswa cenderung pasif, tidak memiliki aktivitas selama pembelajaran berlangsung sehingga suasana kelas tidak hidup. Dalam jangka waktu lama siswa menjadi bosan sehingga akan berdampak kepada hasil belajar ekonomi siswa rendah. Upaya yang dapat dilakukan oleh guru untuk meningkatkan prestasi belajar siswa dengan mengikut sertakan siswa dalam proses pembelajaran. Menurut Anita dalam Cooperative Learning (2006), situasi dalam kelas perlu direncanakan dan dibangun sedemikian rupa sehingga siswa mendapatkan kesempatan untuk berinteraksi satu sama lain. Dalam interaksi ini, akan terbentuk suatu komunitas yang memungkinkan mereka untuk memahami proses belajar dan memahami satu sama lain. Diharapkan, guru dapat menciptakan situasi belajar sedemikian rupa sehingga siswa dapat bekerjasama dalam kelompok serta mengembangkan wawasannya tentang pembelajaran kooperatif.

Sagala (2008). Pendekatan kontekstual Contextual Teaching and Learning disingkat dengan CTL merupakan konsep belajar yang membantu guru mengaitkan antara materi yang diajarkannya dengan situasi dunia nyata siswa dan mendorong siswa membuat hubungan antara pengetahuan yang dimilikinya dengan penerapannya dalam kehidupan mereka. Menurut Trianto (2010) pembelajaran kontekstual adalah konsep belajar yang membantu guru mengaitkan antara materi yang diajarkannya dengan situasi dunia nyata siswa dan mendorong siswa membuat hubungan antara pengetahuan yang dimilikinya dengan penerapannya dalam kehidupan mereka sehari-hari. Menurut Rohman (2009) pembelajaran kontekstual merupakan proses pembelajaran yang holistik dan bertujuan membantu siswa untuk memahami materi pembelajaran yang dipelajarinya dengan mangaitkan materi tersebut dengan konteks kehidupan mareka sehari-hari, sehingga siswa memiliki pengetahuan atau keterampilan yang secara fleksibel dapat diterapkan dari suatu permasalahan atau konteks lain. Menurut Rusma (2011), ada 7 prinsip pembelajaran kontekstual yang harus dikembangkan oleh guru, yaitu: 1) Konstruktivisme, 2) Menemukan, 3) Bertanya, 4) Masyarakat Belajar, 5) 
Pemodelan, 6) Refleksi, 7) Penilaian Sebenarnya.

Berdasarkan beberapa pendekatan di atas terkait dengan pendekatan Contextual Teaching and Learning (CTL) dapat disimpulkan bahwa (CTL) dapat dikatakan sebagai sebuah pendekatan pembelajaran yang mengakui dan menunjukan kondisi alamiah dari pengetahuan. Melalui hubungan di dalam dan di luar kelas, pendekatan Contextual Teaching and Learning (CTL) menjadikan pengalaman lebih relevan dan bagi siswa dalam membangun pengetahuan mereka dalam kehidupannya.

Pikiran dapat diartikan sebagai kondisi yang menghubungakan bagian-bagian pengetahuan yang telah dimiliki dalam diri dan dikontrol oleh akal. Menurut Sagala (2006) berpikir berarti proses menentukan hubungan-hubungan secara bermakna antara aspek-aspek dari suatu bagian pengatahuan. Kemampuan berpikir yang paling rendah adalah mengingat atau pengatahuan, kemampuan berikutnya yaitu kampuan memahami konsep-konsep ekonomi. Sedangkan kamampuan yang lebih tinggi adalah kemampuan berpikir kritis.

Menurut Paul \& Elder (2006) berpendapat bahwa berpikir kritis adalah seni menganalisis dan mengevaluasi pemikiran dengan maksud untuk meningkatkan kemampuan. Kemampuan berpikir kritis sangat erat hubungannya dengan pemrosesan suatu informasi. Ristontowi (2011) berpendapat bahwa berpikir kritis adalah kemampuankemampuan untuk memahami masalah, menyeleksi informasi yang penting untuk menyelasaikan masalah, memahami asumsi-asumsi, merumuskan dan menyelasaikan hipotesis yang relevan, serta mearik kesimpulan yanng valid dan menentukan kevalidan dari kesimpulankesimpulan.

Dari pendapat di atas, maka peneliti menyimpulkan bahwa kemampuan berpikir kritis adalah kemampuan menafsirkan dan menganalisis terhadap informasi yang diterima, diperiksa dan dibandingkan dulu kebenarannya dengan pengetahuan dan pemahaman yang dimiliki sebelumnya sehingga seseorang tersebut mampu memberikan kesimpulan terhadap informasi tersebut dengan alasan yang tepat.

\section{METODE PENELITIAN}

Penelitian ini merupakan penelitian Quasi Eksperimen dengan menggunakan pendekatan kuantitatif karena peneliti tidak merubah keadaan kelompok awal sampel. Desain penelitian dalam ini yaitu "Pretest-post-test non equivalent control group". Penelitian ini akan dilaksanakan di Sekolah Menengah Pertama (SMP) Tulang Bawang Barat Lampung. Penelitian ini akan meneliti siswa kelas VIII dengan jumlah siswa 156 siswa yang terbagi menjadi 5 kelas, kelompok eksperimen yaitu pada kelas VIIIb dan kelompok kontrol pada kelas VIIId. 
Adapun tahapan-tahapan penelitian ini, dapat digambarkan sebagai berikut:

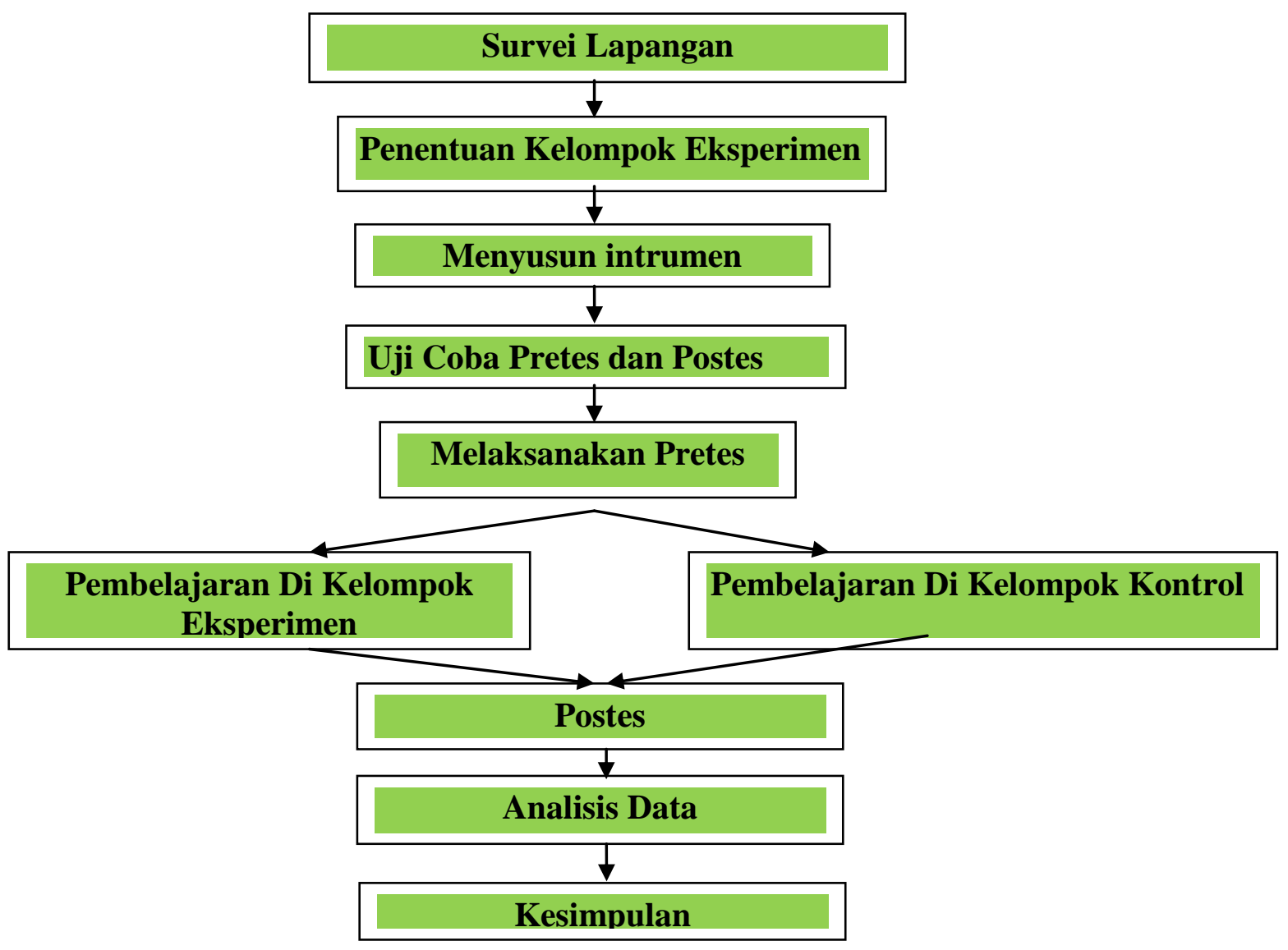

Gambar 3.1 Tahapan penelitian

\section{PEMBAHASAN HASIL PENELITIAN}

Pengolahan data hasil penelitian ini bertujuan untuk membandingkan pencapaian kemampuan berpikir kritis siswa yang mendapatkan pembelajaran dengan pendekatan Contextual Teaching and Learning (CTL) dengan siswa yang memperoleh pembelajaran secara konvensional. Untuk mengukur kemampuan berpikir kritis siswa, digunakan tes berbentuk uraian, yang diberikan kepada siswa sebagai postes. Data skor hasil postes kelas eksperimen dan kelas kontrol dianalisis untuk melihat perbedaan pengaruh pembelajaran kedua kelas. Pada Tabel 1 menunjukkan deskriptif data postes siswa kelas eksperimen dan kelas kontrol untuk kemampuan berpikir kritis siswa.

Data kemampuan berpikir kritis siswa diperoleh dari hasil postes kelas eksperimen dan kelas kontrol.

Tabel 1 Statistik Deskriptif Kemampuan Berpikir kritis siswa

\begin{tabular}{|c|c|c|c|c|c|}
\hline \multirow{2}{*}{ Nilai } & \multicolumn{5}{|c|}{ Postes } \\
\cline { 2 - 6 } & $\mathbf{N}$ & $\mathbf{X}_{\min }$ & $\mathbf{X}_{\text {maks }}$ & $\overline{\boldsymbol{x}}$ & SD \\
\hline Eksperimen & 30 & 55 & 90 & 71,87 & 9,88 \\
\hline
\end{tabular}




\begin{tabular}{|c|c|c|c|c|c|}
\hline Kontrol & 30 & 50 & 85 & 66,26 & 10,50 \\
\hline
\end{tabular}

Berdasarkan Tabel 1. Skor minimum dan maksimum skor postes untuk kelas yang memperoleh pembelajaran Dengan pendekatan Contextual Teaching and Learning (CTL) adalah 55 dan 90 dengan Standar Deviasi 9,88, sedangkan skor minimum dan maksimum skor postes untuk kelas yang memperoleh pembelajaran konvensional adalah 50 dan

Untuk lebih jelasnya Tabel 2, dapat dibuat diagram perbandingan rataan postes sebagai berikut:

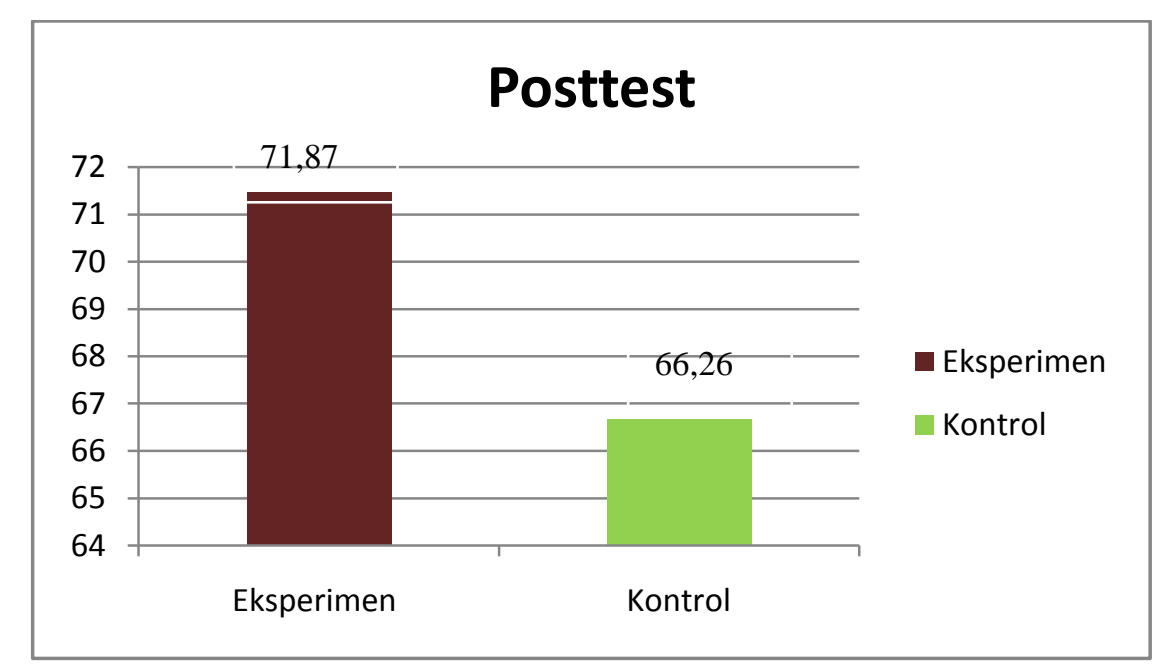

Gambar 2. Perbandingan Rataan Postes Berpikir kritis siswa

Berdasarkan hasil perhitungan uji normalitas skor postes kelas eksperimen dan kontrol dapat dilihat dari Tabel berikut:

Tabel 2 Uji Normalitas Skor Kemampuan Berpikir Kritis Setelah Pembelajaran

\begin{tabular}{ccccccc}
\hline \multirow{2}{*}{ Kelas } & \multicolumn{4}{c}{ Kolmogorov-Smirnov } & Keputusan & Kesimpulan \\
\cline { 2 - 4 } Eksperimen & Statistic & $\boldsymbol{D f}$ & Sig. & & $\begin{array}{c}\text { Data } \\
\text { Berdistribusi } \\
\text { Normal }\end{array}$ \\
\hline Kontrol & 0,128 & 30 & $.200^{*}$ & $\mathrm{H}_{0}:$ diterima & $\begin{array}{c}\text { Data } \\
\text { Berdistribusi } \\
\text { Normal }\end{array}$ \\
\hline
\end{tabular}

$H_{0}$ : sampel berdistribusi normal

Kriteria pengujian adalah dengan $\alpha=$ 0,05. Jika nilai Sig. $>\alpha$, maka $\mathrm{H}_{0}$ diterima.

Berdasarkan tabel tersebut, memiliki nilai Sig. $>\alpha$, yaitu $.200^{*}$ sehingga, skor postes 
kelas ekperimen dan kontrol untuk kemampuan berpikir kritis berdistribusi normal.
Berdasarkan hasil perhitungan uji normalitas skor postes kelas eksperimen dan kontrol dapat dilihat dari Tabel 4 berikut:

\section{Tabel 4 Uji Homogenitas Varians Skor Kemampuan Berpikir Kritis Setelah Pembelajaran}

\begin{tabular}{lccccl}
\hline $\begin{array}{l}\text { Levene } \\
\text { Statistic }\end{array}$ & $\boldsymbol{d f 1}$ & $\boldsymbol{d f 2}$ & Sig. & Keputusan & Kesimpulan \\
\hline 0,071 & 1 & 58 & 0,791 & $\mathrm{H}_{0}$ : diterima & Variansi sama \\
\hline
\end{tabular}

$H_{0}:$ varians kedua kelompok homogen

Berdasarkan Tabel 4 memperlihatkan bahwa skor postes memiliki Sig. lebih besar dari $\alpha=0,05$ yaitu 0,5 untuk postes yaitu 0,791 , sehingga $\mathrm{H}_{0}$ diterima. Hal ini berarti, skor postes kemampuan berpikir kritis siswa kelas eksperimen dan kelas kontrol berasal dari varians yang sama.

Pada tahap selanjutnya adalah Uji Perbedaan Rataan Skor Kemampuan
Berpikir Kritis, Uji ini bertujuan untuk mengetahui perbedaan rataan postes. Berdasarkan hasil uji normalitas dan homogenitas skor postes kelas eksperimen dan kelas kontrol, bahwa data kedua kelas berdistribusi normal dan varians kedua kelas homogen, maka bisa dilanjutkan pada uji perbedaan postes menggunakan Independent sample t-test.

Tabel 5 Uji Perbedaan Rataan Skor Kemampuan Berpikir Kritis Setelah Pembelajaran

\begin{tabular}{|l|l|l|l|l|}
\hline \multicolumn{3}{|l|}{ t-test for Equality of Means } & \multirow{2}{*}{ Keterangan } & \multirow{2}{*}{ Kesimpulan } \\
\hline T & $\boldsymbol{d} \boldsymbol{f}$ & Sig. (2-tailed) & & \\
\hline 2,127 & 58 & 0,038 & $\mathrm{H}_{0}$ Ditolak & Terdapat Perbedaan \\
\hline
\end{tabular}

Berdasarkan hasil uji perbedaan rataan postes kelas eksperimen dan kelas kontrol tersebut diketahui bahwa nilai Sig. (2tailed) yaitu 0,038 lebih kecil dari nilai $\alpha=$ 0,05 , sehingga $\mathrm{H}_{0}$ ditolak. Hasil ini berarti kedua kelas memiliki kemampuan berpikir kritis yang berbeda secara signifikan. Kemampuan berpikir kritis siswa yang mendapat pembelajaran pendekatan Contextual Teaching and Learning (CTL) lebih tinggi dari pada siswa yang mendapat pembelajaran konvensional. Sehingga dapat disimpulkan bahwa terdapat pengaruh pendekatan Contextual
Teaching and Learning (CTL) terhadap berpikir kritis siswa pada mata pelajaran ekonomi.

\section{KESIMPULAN DAN SARAN}

Berdasarkan hasil analisis data mengenai pengaruh model pembelajaran pendekatan Contextual Teaching and Learning (CTL) terhadap kemampuan berpikir kritis siswa SMP NEGERI 1. Maka dikemukakan kesimpulan bahwa "terdapat pengaruh pendekatan Contextual Teaching and Learning (CTL) terhadap 
berpikir kritis siswa pada mata pelajaran ekonomi”.

Berdasarkan hasil penelitian kemajuan yang diperoleh, maka saran yang sekiranya dapat diberikan peneliti sebagai bahan pertimbangan untuk perbaikan proses pembelajaran adalah sebagai berikut : Saran untuk penelitian kemajuan ini sebagai berikut:

Hasil penelitian ini menunjukkan bahwa model pembelajaran pendekatan Contextual Teaching and Learning (CTL) dapat meningkatkan kemampuan berpikir kritis siswa. Sebaiknya pembelajaran dengan menggunakan model pembelajaran pendekatan Contextual Teaching and Learning (CTL) dapat digunakan sebagai upaya untuk meningkatkan kemampuan berpikir kritis siswa.

\section{DAFTAR PUSTAKA}

Anita Lie. 2007. Cooperative Learning. Jakarta: Grasindo.

Sagala, S (2008). Belajar dan FaktorFaktor yang Mempengaruhnya. Jakarta: Rineka Cipta.

Trianto. 2010. Mendesain Model Pembelajaran Inovatif-Progresif. Jakarta? Kencana Prenada Media Group

Rohman, Arif. 2009. Memahami Pendidikan dan Ilmu Pendidikan. Jogjakarta: Laks Bang Meditama.

Rusman. 2011. Model-Model Pembelajran Mengembangkan Profeionalisme Guru. Jakarta. Pt Raja Grafindo Persada
Ristontowi. 2011. Mengembangkan Kemampuan Berpikir Matematis Siswa melalui Pembelajaran Creative Problem Solving. Prosiding Seminar Nasional Pendidikan MIPA.

Paul, R and Elder, L. (2006). Critical thiking: the art of socratic questioning journal of developmental education, 31 (1), 3637 